\title{
Trichoderma: a beneficial antifungal agent and insights into its mechanism of biocontrol potential
}

\author{
Ria Mukhopadhyay ${ }^{1 *}$ and Deepak Kumar ${ }^{2}$
}

\begin{abstract}
Background: Agriculture is an indispensable part of any country to feed the millions of people but it is under constant threat of pests. To protect the crops from this huge yield loss recently, chemical pesticides are used. Though chemical pesticides have shown effective results in killing the crop pests, it causes negative impact on the environment as well as humans. So to find an eco-friendly alternative, biological control methods are being used.

Main body: Biological control is a great renaissance of interest and research in microbiological balance to control soil-borne plant pathogens and leads to the development of a better farming system. In biological control, genus Trichoderma serves as one of the best bioagents, which is found to be effective against a wide range of soil and foliar pathogens. Genus Trichoderma is a soil inhabiting green filamentous fungus, which belongs to the division Ascomycota. The efficacy of Trichoderma depends on many abiotic parameters such as soil pH, water retention, temperature and presence of heavy metals. The biocontrol potential of Trichoderma spp. is due to their complex interaction with plant pathogens either by parasitizing them, secreting antibiotics or by competing for space and nutrients. During mycoparasitic interactions, production of hydrolytic enzymes such as glucanase, chitinase and protease and also signalling pathways are initiated by Trichoderma spp. and the important ones are Heterotrimeric G protein, MAP kinase and cAMP pathway. G protein and MAPK are mainly involved in secretion of antifungal metabolites and the formation of infection structures. CAMP pathway helps in the condition and coiling of Trichoderma mycelium on pathogenic fungi and inhibits their proliferation.
\end{abstract}

Short conclusion: Trichoderma being an efficient biocontrol agent, their characteristics and mechanisms should be well understood to apply them in field conditions to restrict the proliferation of phytopathogens.

Keywords: Trichoderma spp., Plant pathogens, Biocontrol, Mode of action, Signalling pathway

\section{Background}

Plant diseases caused by fungi and bacteria result in severe losses to agriculturally important crops. Plant disease control by chemical methods has many unwanted health, safety and environmental risks. Biological control is a potent mean of reducing the damage caused by plant pathogens and is environmentally non-hazardous. Many

\footnotetext{
* Correspondence: ria.mukhopadhyay@cutm.ac.in

'Department of Plant Pathology, MS Swaminathan School of Agriculture, Centurion University of Technology and Management, Paralakhemundi, Odisha, India

Full list of author information is available at the end of the article
}

species in this genus can be characterized as opportunistic virulent plant symbionts (Harman et al. 2004). Trichoderma taxonomy has been classified based on the differences in its morphological characters and sporulation. The species of Trichoderma uses several mechanisms to control the growth and proliferation of harmful pathogens such as parasitism, competition and antibiosis. Biocontrol agent like Trichoderma has been an integral part of Integrated Pest Management (IPM) to control the pests and diseases in an environmentally friendly manner (Monte, 2001).

\section{Springer Open}

(c) The Author(s). 2020 Open Access This article is licensed under a Creative Commons Attribution 4.0 International License, which permits use, sharing, adaptation, distribution and reproduction in any medium or format, as long as you give appropriate credit to the original author(s) and the source, provide a link to the Creative Commons licence, and indicate if changes were made. The images or other third party material in this article are included in the article's Creative Commons licence, unless indicated otherwise in a credit line to the material. If material is not included in the article's Creative Commons licence and your intended use is not permitted by statutory regulation or exceeds the permitted use, you will need to obtain permission directly from the copyright holder. To view a copy of this licence, visit http://creativecommons.org/licenses/by/4.0/. 


\section{Main text \\ Insights on Trichoderma and its biocontrol mechanism Taxonomy}

The first description of the genus Trichoderma was in 1794 by Persoon, and Tulasne and Tulasne suggested the sexual state of a Hypocrea species in 1865. Cook and Baker (1983) described genus Trichoderma as a common soil inhabitant and the conidiophores are terminating in phialides. Doi and Doi (1986) recognized 63 species under this genus and included some anamorphs of genus Hypocrea that were previously placed under genera Verticillium and Gliocladium, where each having irregularly branched conidiophores and elongated phialides. Bissett (1984) worked on subgrouping the species under genus Trichoderma into 5 sections, i.e., Trichoderma, Longibrachiatum, Saturnisporum, Pachybasium and then the fifth new section of Hypocreanum arose.

For more species identification, other criteria have also been used. Zamir and Chet (1985) applied enzyme electrophoresis for Trichoderma harzianum identification and isozyme polymorphism was demonstrated. Another diagnostic approach known as scanning electron microscope (SEM) was used (Hashioka, 1973), which revealed the presence of sheath material with epispore scars. Schlick et al. (1994) firstly used randomly amplified PCR fingerprinting (RAPD) to distinguish between gamma irradiated mutants and wild strains of $T$. harzianum that was found to be the most effective tool. Kindermann et al. (1999) used the nucleotide sequences of the internal transcribed spacer region one of rDNA to investigate phylogenetic relation among Trichoderma species of the section Pachybasium, which was found to be nonmonophyletic.

The different species of the genus, Trichoderma/Hypocrea were difficult to be distinguished morphologically. It was even proposed to reduce taxonomy to only a single species, T. viride (Schuster and Schmoll, 2010). Nowadays, new species can be easily identified due to the development of TrichOKEY, where an oligonucleotide barcode and TrichoBLAST became a search tool. These are easily available online at www.isth.info (Druzhinina et al. 2005; and Kopchinskiy et al. 2005). Recently, according to Kamala et al. (2015) Trichoderma species belongs to the division Ascomycota, subdivision Pezizomycotina, class Sordariomycetes, subclass Hypocreomycetidae, order Hypocreales and family Hypocreaceae. Chaverri et al. (2015) have reidentified the ubiquitous Trichoderma harzianum into 14 new species with various characteristics.

\section{Morphology}

Rifai (1969) and Domsch et al. (1980) described colonies of Trichoderma spp. in culture to be floccose, tufted green, growing rapidly and sporulate well under incandescent light than otherwise, often producing spores in bands. Phialides of Trichoderma spp. are sterile hyphae creeping septate forming a flat, firm, tuft conidiophores erect arising from a short branch. In $T$. viride, conidia have double-layered walls consisting of an electron dense rough outer layer (epispore) and a moderate electron dense inner layer. Around the conidia and hyphae, a distinct mucilaginous substance is present (Hashioka et al. 1996). Majumdar (1993) and Sengupta (1995) stated that chlamydospores are formed late in cultural media, intercalary or rarely terminal, round and doublewalled function as resting spores during unfavourable conditions. Recently, micromorphology of Trichoderma reese $i$ has been studied by confocal laser scanning microscope to see the branching pattern of the fungus which produces cellulolytic enzymes (Novy et al. 2016).

\section{Characteristics}

Trichoderma spp. are often found wherever decaying plant materials are available mainly of cellulosic materials (Kubicek et al. 2009 and Jaklitsch, 2009). Trichoderma spp. are mainly characterized by branched conidiophorebearing bright green conidia (Gams and Bissett, 1998). Figure 1 demonstrates the conidiophores containing phialides and phialospores of T. harzianum. According to Shah et al. (2012), the light green conidia of T. harzianum are globose to subglobose, while those of $T$. viride are globose. Small pale green conidia were observed in $T$. pseudokoningii.

\section{Trichoderma as a bioagent}

The use of microorganisms as bioagents is a less hazardous method for controlling plant pathogens. Almost 20 species of the genus Trichoderma act as bioagents against many soil-borne as well as foliar plant pathogens. T. harzianum, T. koningii, T. viride, T. atroviride, T. pseudokoningii, T. longibrachiatum, T. hamatum, T. polysporum and $T$. reese $i$ are the most important species, which act as potential antagonists (Monaco et al. 1991). Antagonism of Trichoderma against different pathogens has been reported for several times like Sclerotium rolsfii (Mukherjee and Tripathi, 2000), Fusarium ciceris, Macrophomina phaseolina, Rhizoctonia solani (Mukhopadhyay and Pan 2012a) and plant parasitic nematodes (Spiegel and Chet, 1998). Mukherjee and Raghu (1997) observed that Trichoderma species and Gliocladium virens were highly effective in suppressing $S$. rolsfii on ginger rhizomes and on several vegetables in storage. Li et al. (2018) showed that 4 species of Trichoderma restricted Fusarium oxysporum growth by producing volatile compounds.

\section{Influence of environmental factors on biocontrol potential of Trichoderma strains}

Among the Trichoderma species, the optimum temperature for the growth is different (Samuels, 1996), 

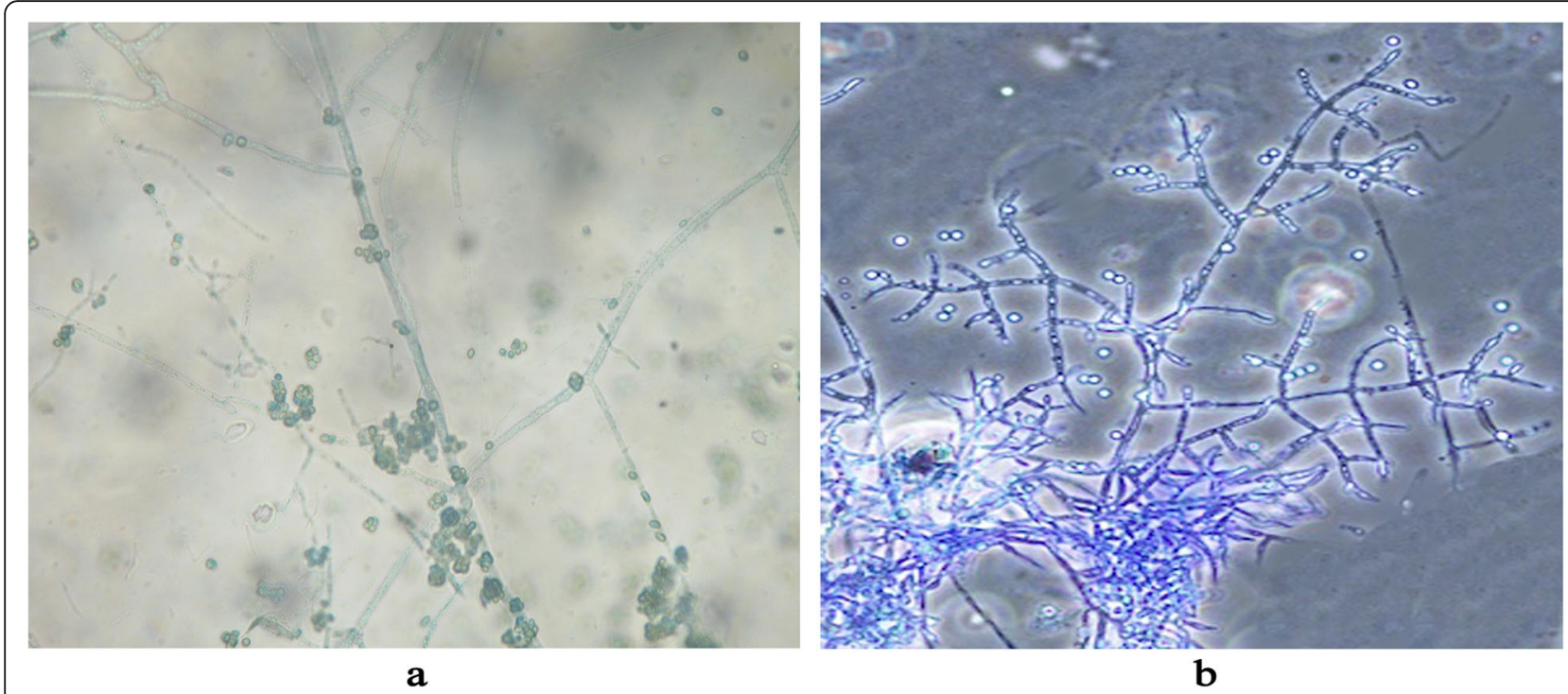

Fig. 1 Phialides and phialospores of $\mathbf{a}$ Trichoderma harzianum and $\mathbf{b}$ Trichoderma viride (taken from the Université de Bretagne Occidentale website)

but mostly they are mesophilic. Water conditions have been shown to strongly effect on Trichoderma activities, most particularly spore germination, germ tube growth (Magan, 1988), mycelial growth (Lupo et al. 2002), the interaction with other fungi (Badham, 1991) and on enzyme production (Grajek and Gervais, 1987). At higher water potential, optimum secretion of cellobiohydrolase and NAGase enzymes were observed, while the maximum activities of secreted glucosidase, xylosidase and chymotrypsin-like protease enzymes occurred at lower water potential values than those optimal for growth. Some examined Trichoderma strains were able to grow in a wide range of $\mathrm{pH}$ from 2.0 to 6.0 with an optimum at 4.0. Mycelial growth of Trichoderma strains was also affected by the presence of heavy metals. Zehra et al. (2017) tested Trichoderma spp. against Alternaria alternata, F. oxysporum in different environmental conditions such as salt, temperature and $\mathrm{pH}$ and found $T$. harzianum to be most effective

\section{Biocontrol mechanisms of Trichoderma spp.}

The main three mechanisms of biocontrol of Trichoderma spp. are mycoparasitism, antibiosis, and competition for nutrients or space among others which may operate independently or together to suppress plant pathogens.

\section{Mycoparasitism}

Haran et al. (1996) proposed the mycoparasitic activity (hyperparasitism) of Trichoderma as one of the major mechanisms involved in their antagonistic activities against phytopathogenic fungi. The importance of Trichoderma's mycoparasitism in the biological control of wood decay fungi was discussed by Kumar et al. (1998), who investigated the hyperparasitism of $T$. harzianum by forming appressoria over the pathogenic hyphae of $F$. solani by lightly coiling around them within $95 \mathrm{~h}$ of contact. They added that within 6 days, the fungus was completely inhibited, while $T$. harzianum was multiplied by conidiogenesis. T. gamsii showed mycoparasitic activities as well as antibiosis against phytopathogens (Chen et al. 2016). In Fig. 2a and b, the microscopic observations on hyphal interaction showed that antagonist, sometimes, grew parallel to the hyphae of the tested pathogen, coiled around and penetrated into the hyphae of the pathogen by producing hook or knob-like structure (appresorium) (Mukhopadhyay and Pan, 2012a).

\section{Antibiosis}

Antibiosis is one of the important attributes in deciding the saprophytic ability of the fungus. A range of antibiotics produced by species of Trichoderma and Gliocladium, which has been suggested as a mode of action of both fungi against plant pathogens was reported by Weindling (1934). Manibhusanrao et al. (1989) reported that antibiotics like trichodermin, suzukacillin and alamethicin produced by $T$. harzianum influence morphological or physiological sequences leading to its successful penetration. Trichoderma spp. and Gliocladium spp. inhibited the growth of broad range of soil-borne fungi viz. genera of Fusarium, Macrophomina, Pythium, Phytophthora, Rhizoctonia, Sclerotinia, Sclerotium and Verticillium (Zaher et al. 2013; Ragab et al. 2015 and Chen et al. 2016). do Nascimento Silva et al., (1998) demonstrated the in vitro antagonistic potential of 3 Trichoderma spp. against Colletotrichum gloeosporioides on passion fruit. Trichoderma spp. antagonistic to a range of pathogenic 

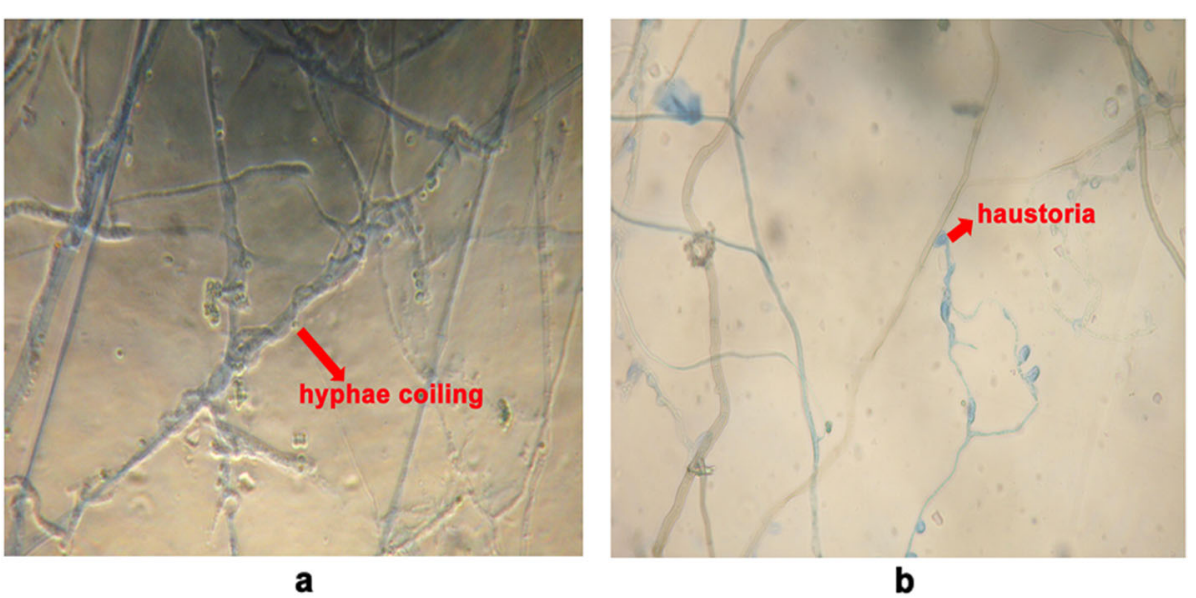

Fig. 2 Mycoparasitism by Trichoderma hyphae a coiling around the hyphae of Rhizoctonia solani and $\mathbf{b}$ producing haustoria to inhibit growth of Macrophomina sp.

fungi was reported to be producing volatile and nonvolatile antibiotics (Mukhopadhyay and Kaur, 1990). Studies on the production of volatile and non-volatile antibiotics revealed that $T$. harzianum and $T$. viride were highly effective in reducing the radial growth of S. rolfsii (Rao and Kulkarni, 2003). Mukhopadhyay and Pan (2012a) stated that T. viride was the most potential antagonist based on volatile and non-volatile antibiotics. Five local isolates of the bioagents, T. harzianum, T. viride, T. aureoviride and G. virens isolated from ginger rhizosphere were evaluated in vitro to assess their mode of antagonism against $R$. solani, infecting Capsicum annuum and $C$. frutescens. It was observed that the non-volatile antibiotics were more effective than the volatile antibiotics (Bunker and Mathur, 2001).

Bhagat and Pan (2010) screened 12 isolates of Trichoderma spp. in vitro against $R$. solani Kuhn. causing root and collar rot of French bean (Phaseolus vulgaris L.) by dual culture tests and production of volatile and non-volatile antibiotics and it was found that all the isolates significantly inhibited the mycelial growth of $R$. solani.

\section{Competition}

Bioagents compete for nutrients and space with pathogens and, thus, it is the injurious effect of one microorganism to another due to the utilization or removal of some resources from the environment. Competition between iron containing siderophore of Trichoderma and wood decay Basidiomycetes fungi was investigated by Srinivasan et al. (1995).

\section{Biopriming and field evaluation of Trichoderma spp.}

The biocontrol fungi, Trichoderma spp., are not only able to control the pathogens causing plant disease, but can also induce seed germination, seedling emergence and promote plant growth. Vinale et al. (2004) reported that in greenhouse and field trials, T. harzianum and $T$. atroviride improved the growth of lettuce, tomato and pepper plants and productivity was increased up to $300 \%$ than the untreated control. Similarly, several scientists have got positive results of disease control and increased plant growth and yield in vivo and under field conditions (Harman et al. 2003, Dubey et al. 2007; Bhagat and Pan, 2008; Joshi et al. 2010 and Mukhopadhyay and Pan, $2012 \mathrm{~b})$. Seed treatment with bioagents for protection of seeds and control of seed borne diseases offers effective biocontrol agents that have been developed for the control of seed and seedling pathogens such as Pythium spp., $R$. solani, S. rolfsii, M. phaseolina and Fusarium spp., which offer the farmers alternative means to chemical fungicides (Dubey et al. 2007 and Nirmalkar et al. 2017).

The efficacy of biological seed treatment can be affected by moisture, temperature and inoculums densities of the pathogen (Mathre et al. 1994) and also by soil pH and iron concentration (Weller, 1988). Efficacy can also be controlled by inoculum density of the bioagents on the seed adjunct treatment such as priming formulation and additives that enhance the activity and survival of the bioagent in the formulated product, crop and pathogen specificity of the bioagent and compatibility with other microbial inoculants. Precolonization provides the bioagent with a competitive advantage over seed attacking pathogens and often provides superior seed protection when compared to seed coating (Harman et al. 1989). Bioagents are effective as a seed treatment, since they colonize roots, increase root mass, health and consequently frequently provide yield increases (Mukhopadhyay et al. 2012b). 


\section{Molecular approaches of genus Trichoderma and its benefits}

Lytic enzymes and biocontrol An insight into the characters of genus Trichoderma at the molecular level would help in developing Trichoderma strains with excellent biocontrol properties. Several hundreds of genes and their products might be involved, which give genus Trichoderma its properties of biocontrol and plant growth enhancement. Hydrolytic enzymes such as glucanase, chitinase and protease are the key players that give Trichoderma the mycoparasitism properties (Haran et al. 1996). 1,4- $\beta$-N-acetylglucosaminidases, endo and exochitinases were reported to be secreted by Trichoderma spp. that help the fungus to improve its biocontrol potential. $\beta$-glucanase produced by Trichoderma spp. degrades $\beta$-glucan the structural component of the attacking pathogen. 1,3$\beta$ glucosidase purified from $T$. harzianum by Lorito et al. (1994), which inhibited germ tube elongation and spore germination of Botrytis cinerea. Proteinase from Trichoderma spp. is also involved in mycoparasitism. PRA1, a trypsin protease purified from $T$. harzianum CECT 2413 strain showed nematicidal effects by destroying the hatched eggs of Meloidogyne incognita (Suarez et al. 2004). Chitinase and protease activity produced by Trichoderma spp. helped to control Sclerotium rolfsii pathogen in groundnut (Parmar et al. 2015).

\section{Signalling pathways involved in biocontrol mechanism}

G protein signalling Neer in 1995 showed that G protein signalling is basically heterotrimeric and constitutes of 3 parts: a G protein-coupled receptor (GPCR), a heterotrimeric $G$ protein ( $\alpha, \beta, \gamma$ subunits) and an effector. Heterotrimeric $G$ proteins are signal transducers that couple cell surface receptors to cytoplasmic effector proteins and transmit the signal to the MAPK and cAMP signalling pathways (Fig. 3). In fungi, G proteins help during sexual and pathogenic development, secondary metabolism and virulence of the pathogens. T. atroviride subgroup I Go subunit Tga1 was analysed by tgal gene over-expression and silencing which showed that it is involved in both coiling and condition (Rocha-Ramirez et al. 2002). Reithner et al. (2005) characterized the Tga1 mutant and showed that the $G$ protein subunit affects processes involved in Trichoderma biocontrol like chitinase formation and production of antifungal metabolites which are important for biocontrol by Trichoderma. He also proved that $\Delta \operatorname{tga} 1$ mutant was not able to overgrow and lyse the host fungi such as $B$. cinerea, $R$. solani and $S$. sclerotiorum. Homologue of Tga1 of T. atroviride, i.e., TgaA and $\mathrm{TgaB}$ did not show such effects in $T$. virens and also showed different effects in controlling pathogenic fungi such as $R$. solani and $S$. sclerotiorum (Mukherjee et al. 2004). Zeilinger et al. (2005) showed that Tga3 protein of T. atroviride is involved in controlling vegetative growth and conidiation and thus $\Delta \operatorname{tga} 3$

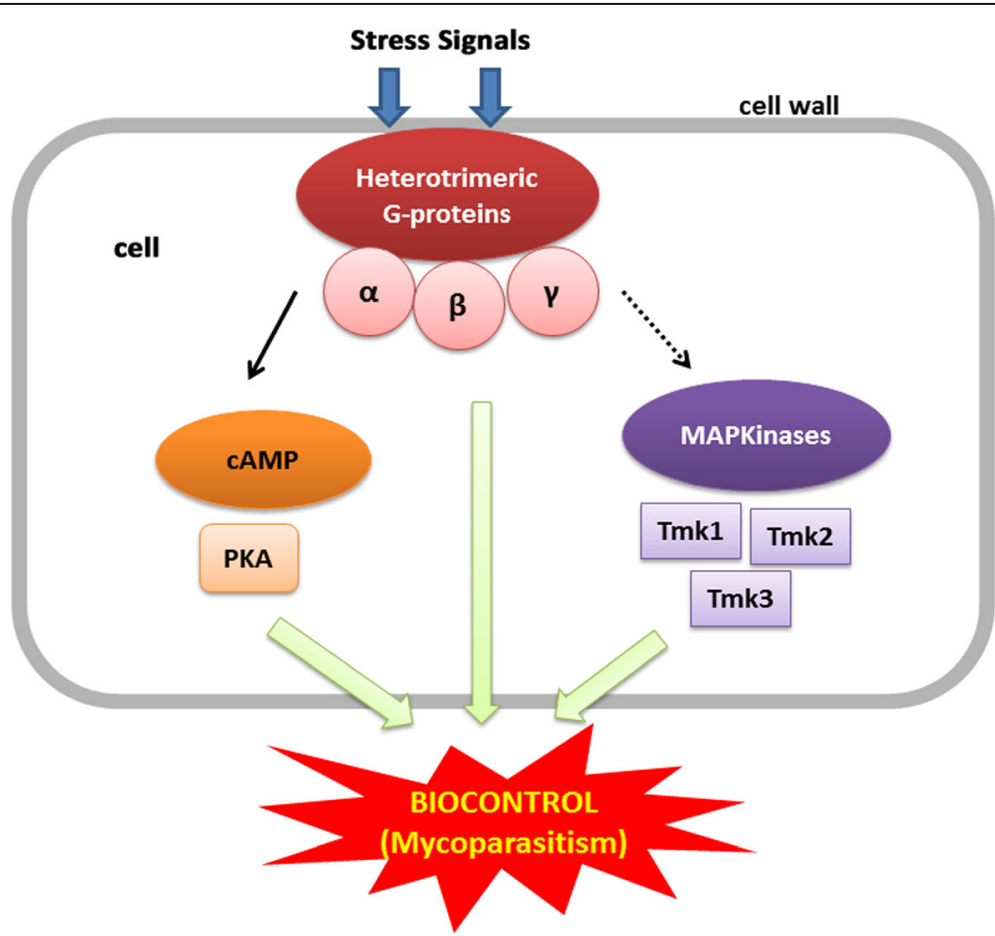

Fig. 3 Schematic representation of signalling pathways involved in mycoparasitism 
knockout mutants produced significantly lesser intracellular cAMP levels in comparison to the parental strain. According to experiments done by do Nascimento Silva (2009), intracellular cAMP levels increased at several folds in T. reesei, since it carries an activated allele of the subgroup III $\mathrm{G} \alpha$ protein-encoding Tga3 homologue gna3. TBRG-1 which bears the domain of RasGTPase helps in conidiation of Trichoderma but its lack causes positive effects on antibiosis mechanism (Castro et al. 2020).

\section{Mitogen-activated protein kinases}

MAPK cascades are found in all eukaryotes and are organized in a 3 kinase architecture comprising of a MAPK, MAPK kinase or MEK and MEK kinase or MEKK or MAPK kinase kinase. In Trichoderma, the best observed MAPKs are yeast and fungal extracellularrelated kinases (YERK1), and also MAPKs such as Fmk1 from Fusarium oxysporum, Pmk1 from Magnaporthe grisea, Ubc3/Kpp2 from Ustilago maydis, or Bmp1 from $B$. cinerea (Zeilinger et al. 2007). The MAPKs in different species of Trichoderma are more or less similar as described by Reithner et al. (2007). According to his findings, there is almost $98 \%$ similarity in MAPKs of $T$. atroviride (Tmk1) and T. virens (TmkA/Tvk1).

MAPK signalling is important in Trichoderma to induce full systemic resistance in plants. TmkA MAPK loss-of-function mutants of $T$. virens can colonize the roots of cucumber plants against Pseudomonas syringae pv. lacrymans but cannot induce systemic resistance against the pathogen (Viterbo et al. 2005). MAPK cascades traduce signals by sequential phosphorylation of kinases. Inactivation of MAP kinase gene tvk 1 in mutant line of Trichoderma showed increased mycoparasitism and decreased the growth of the fungus $R$. solani (Mendoza-Mendoza et al. 2003). Esquivel-Naranjo et al. (2016) showed that in T. atroviride, the mutants lacking the MAPKK gene Pbs2 and the MAPK Tmk3 were found to be highly sensitive towards cellular stress such as cell wall damage, osmotic and oxidative stress, UV irradiation and high temperature.

\section{cAMP pathway}

cAMP signalling in fungi helps in many cellular processes such as the sexual development, virulence, control of differentiation, monitoring of the nutritional status and stress. But the most important function of cAMP signalling is regulation of transcription and cell cycle. In eukaryotes, almost all the effects of cAMP are due to stimulation of cAMP-dependent protein kinases (PKA) (Dickman and Yarden, 1999). Functional PKA is found to be involved in plant pathogenic fungi, processes like growth, morphogenesis and virulence (Xu and Hamer, 1996). The process of sporulation is the main mechanism for survival and spread of Trichoderma in the environment. These processes are induced by environmental factors. cAMP plays a pivotal role in signalling during sporulation as investigated in $T$. viride and $T$. atroviride by Casas-Flores et al. (2006). cAMP along with the activators of $\mathrm{G}$ protein-mediated signal induce the mycoparasitic behaviour of $T$. harzianum by increasing the coiling behaviour of hyphae (Omero et al. 1999). Nogueira et al. (2015) observed that in $T$. reesei cAMP regulates cellulase expression depending on carbon source. The cel7a and cel6a genes were expressed in higher amounts in sporophose which increased cAMP levels and regulated secretion of cellulolytic enzymes.

\section{Conclusion}

Trichoderma can be an important component in IPM strategies. Biocontrol mechanisms of various species of Trichoderma have been isolated and studied. They restrict the growth and proliferation of the pathogens by parasitism and antibiosis as well as molecular approaches are being done. Different signalling pathways are being studied to gain further insights in the biocontrol mechanism of Trichoderma.

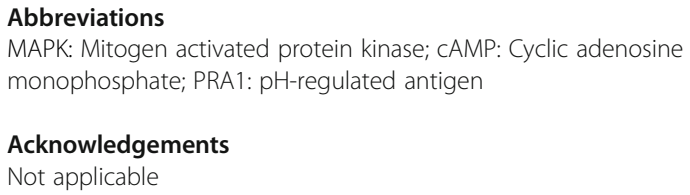

${ }^{1}$ Department of Plant Pathology, MS Swaminathan School of Agriculture, Centurion University of Technology and Management, Paralakhemundi, Odisha, India. ${ }^{2}$ Department of Biochemistry, College of Agriculture, UttarBanga Krishi Viswavidyalaya, Majhian, West Bengal, India.

Received: 11 May 2020 Accepted: 13 October 2020

Published online: 29 October 2020

\section{References}

Badham ER (1991) Growth and competition between Lentinus edodes and Trichoderma harzianum on sawdust substrates. Mycologia 83:455-463

Bhagat S, Pan S (2008) Variability in production of extra cellular hydrolytic enzymes by Trichoderma spp. and induction of disease resistance in gram (Cicer arietinum). J Biol Cont 22:57-66 
Bhagat S, Pan S (2010) Biological management of root and collar rot (Rhizoctonia solani) of French bean (Phaseolus vulgaris). Indian J Agric Sci 80(1):42-50

Bissett J (1984) A revision of the genus Trichoderma.l. Section Longibrachiatum. Sec. Nov. Can J Bot 62:924-931

Bunker RN, Mathur K (2001) Antagonism of local biocontrol agents to Rhizoctonia solani inciting dry root rot of chilli. J. Mycol PI Pathol 31:337-353

Casas-Flores S, Rios-Momberg M, Rosales-Saavedra T, Martínez-Hernández P, Olmedo-Monfil V, Herrera-Estrella A (2006) Cross talk between a fungal bluelight perception system and the cyclic AMP signaling pathway. Eukaryot Cell 5(3):499-506

Castro MD, Rivera ME, Martfnez IO, Carmen M, Medina R, Osuna MI, Flores SC (2020) TBRG-1 a Ras like protein in Trichoderma virens involved in conidiation, development, secondary metabolism, mycoparasitism and biocontrol unveils a new family of Ras-GTPases. Fungal Genet Biol 136. https://doi.org/10.1016/j. fgb.2019.103292

Chaverri P, Rocha FB, Jaklitsch W, Gazis R, Degenkolb T, Samuels GJ (2015) Systematics of the Trichoderma harzianum species complex and the reidentification of commercial biocontrol strains. Mycologia 107:558-590

Chen J, Sun S, Miao C, Wu K, Chen Y, Xu L, Guan H, Zao L (2016) Endophytic Trichoderma gamsii YIM PH30019: a promising biocontrol agent with hyperosmolar, mycoparasitism and antagonistic activities of induced volatile organic compounds on on root rot pathogenic fungi of Panax notoginseng. J Ginseng Res 40:315-324

Cook RJ, Baker KF (1983) The nature and practice of biological control of plant pathogens. American Phytopathological Society Press St. Paul, Minnesota. 539

Dickman MB, Yarden O (1999) Serine/threonine protein kinase and phosphatases in filamentious fungi. Fungal Genet Biol 26(2):99-117

do Nascimento Silva R, Sousha Rocha J de R de, Oliveira NT de (1998) In vitro antagonistic potential of Trichoderma spp. against Colletotrichum gloeosporioides agent of anthracnose in passion fruit (Passiflora). BoletinMicologico 13(1/2):103-110

do Nascimento Silva R, Steindorff AS, Ulhoa CJ, Félix CR (2009) Involvement of Galpha protein GNA3 in production of cell wall-degrading enzymes by Trichoderma reesei (Hypocrea jecorina) during mycoparasitism against Pythium ultimum. Biotechnol Lett 31(4):531-536

Doi N, Doi Y (1986) Notes on Trichoderma and its allies. 2 comparison of the Trichoderma states of Hypocrea albofulfa B. et. Br. and H. nigricans (I mai) Doi. Bullet Nat Sci Tokyo 6:41-54

Domsch KH, Gams W, Anderson TH (1980) Trichoderma pero. Ex Fries, 1821. In compendium of soil fungi, Vol 1 pp: 368-377, 794-809, Academic Press, London, New York

Druzhinina IS, Kopchinskiy AG, Komon M, Bissett J, Szakacs G, Kubicek CP (2005) An oligonucleotide barcode for species identification in Trichoderma and Hypocrea. Fungal Genet Biol 42:813-828

Dubey SC, Suresh M, Singh B (2007) Evaluation of Trichoderma species against Fusarium oxysporum f.sp. ciceri for integrated management of chickpea wilt. Biol Control 40(1):118-127

Esquivel-Naranjo EU, Garcla-Esquivel M, Medina-Castellanos E, Correa-Perez VA, Parra-Arriaga JL, Landeros-Jaime F, Cervantes-Chavez JA, Herrera-Estrella A (2016) A Trichoderma atroviride stress-activated MAPK pathway integrates stress and light signals. Mol Microbiol 100(5):860-876

Gams W, Bissett J (1998) Morphology and identification of Trichoderma. In: Harmann GE, Kubicek CP (eds) Trichoderma and Gliocladium. Taylor and Francis, London, pp 3-34

Grajek W, Gervais P (1987) Influence of water activity on the enzyme biosynthesis and enzyme activities produced by Trichoderma viride TS in solid-state fermentation. Enzyme Microb Technol 9:658-662

Haran S, Schickler H, Chet I (1996) Molecular mechanisms of lytic enzymes involved in the biocontrol activity of Trichoderma harzianum. Microbiology 142(9):2321-2331

Harman GE, Howell CR, Viterbo A, Chet I, Lorito M (2004) Trichoderma species-opportunistic avirulent plant symbionts. Nat Rev Microbiol 2(1):4356

Harman GE, Petzoldt R, Comis A, Chen J (2003) Interaction between Trichoderma strain T22 and maize inbred line Mo17 and effects of these interactions on diseases caused by Pythium ultimum and Colletotrichum graminicola. Phytopathology 94:147-153

Harman GE, Taylor AG, Stasz TE (1989) Combining effective strains of Trichoderma harzianum and solid matrix priming to improve biological control seed treatment. Phytopathology 73:631-637
Hashioka J (1973) Screening electron microscopy of the mycoparasites Trichoderma, Gliocladium and Acremonium. Rep Tottri Mycol Inst 10:473-484

Hashioka Y, Horino O, Kamei T (1996) Electron micrographs of Trichoderma and Pachybasidia. Rept Tottori Mycol Inst (Japan) 5:18-24

Jaklitsch WM (2009) European species of Hypocrea. Part I. The green-spored species. Stud Mycol 63:1-91

Joshi BB, Bhatt RP, Bahukhandi D (2010) Antagonistic and plant growth activity of Trichoderma isolates of Western Himalayas. J Environ Biol 31(6):921-928

Kamala T, Indira Devi S, Sharma KC, Kennedy K (2015) Phylogeny and taxonomical investigation of Trichoderma spp. from Indian region of IndoBurma biodiversity hot spot region with special reference to Manipur. BioMed Res Int. https://doi.org/10.1155/2015/285261

Kindermann J, El Ayouti Y, Samuels GJ, Kubicek CP (1999) Phylogeny of the genus Trichoderma based on sequence analysis of the internal transcribed spacer region 1 of the rDNA cluster. Fungal Genet Biol 24(3):298-309

Kopchinskiy A, Komon M, Kubicek CP, Druzhinina IS (2005) TrichoBLAST: a multilocus database for Trichoderma and Hypocrea identifications. Mycol Res 109:658-660

Kubicek CP, Mikus M, Schuster A, Schmoll M, Seiboth B (2009) Metabolic engineering strategies for the improvement of cellulose production by Hypocrea jecorina. Biotechnol Biofuel 2:19

Kumar V, Sharma DD, Babu AM, Datta RK (1998) SEM studies on the hyphal interaction between a biocontrol agent T. harzianum and mycopathogen Fusarium causing root rot disease in mulberry. Ind J Seric 37(1):17-20

Li N, Alfiky A, Wang W, Islam M, Nourollahi K, Liu X, Kang S (2018) Volatile compound-mediated recognition and inhibition between Trichoderma biocontrol agents and Fusarium oxysporum. Front Microbiol. https://doi.org/ 10.3389/fmicb.2018.02614

Lorito M, Peterbauer C, Hayes CK, Harman GE (1994) Synergistic interaction between fungal cell wall degrading enzymes and different antifungal compounds enhances inhibition of spore germination. Microbiology 140: 623-629

Magan N (1988) Effects of water potential and temperature on spore germination and germ-tube growth in vitro and on straw leaf sheaths. Trans Bri Mycol Soc 90:97-107

Majumdar D (1993) Hyperparasitic potential of a few biotypes of Trichoderma harzianum and Gliocladium virens against two pathogens of Betel vine (Piper betel). M. Sc. Dissertation, B.C.K.V., Mohanpur 54-82

Manibhusanrao K, Sreenivasaprasad S, Baby UF, Joe Y (1989) Susceptibility of rice sheath pathogen to mycoparasites. Curr Sci 58(9):515-518

Mathre DE, Callan NW, Johnston RH, Schewnd A (1994) Factors influencing the control of Pythium ultimum induced seed decay by seed treatment with Pseudomonas aureofasciens AB254. Crop Prot 13:301-307

Mendoza-Mendoza A, Pozo MJ, Grzegorski D, Martınez P, Garcıa JM, OlmedoMonfil V, Cortes C, Kenerley C, Herrera-Estrella A (2003) Enhanced biocontrol activity of Trichoderma through inactivation of a mitogen-activated protein kinase. PNAS 100(26):15965-15970

Monaco C, Perello A, Alippi HE, Pasquare AO (1991) Trichoderma spp.: biocontrol agent of Fusarium spp. and Sclerotium rolfsii by seed treatment. Adv Hort Sci 5(3):92-95

Monte E (2001) Understanding Trichoderma: between biotechnology and microbial ecology. Int Microbiol 4:1-4

Mukherjee PK, Latha J, Hadar R, Horwitz BA (2004) Role of two G-protein alpha subunits, TgaA and TgaB, in the antagonism of plant pathogens by Trichoderma virens. Appl Environ Microbiol 70(1):542-549

Mukherjee PK, Raghu K (1997) Effect of temperature on antagonistic and biocontrol potential of Trichoderma spp., on Sclerotium rolfsii. Mycopathologia 139:151-155

Mukherjee S, Tripathi HS (2000) Biological and chemical control of wilt complex of French bean. J Mycol Plant Pathol 30:380-385

Mukhopadhyay AN, Kaur NP (1990) Biological control of chickpea wilt complex by Trichoderma harzianum. Proceedings of Third International Conference on Plant Protection in the Tropics, Malaysia 20-23

Mukhopadhyay R, Pan SK (2012a) Isolation and selection of some antagonistic Trichoderma species from different new alluvial zones of Nadia district, West Bengal. J Bot Soc Bengal 66(2):149-152

Mukhopadhyay R, Pan SK (2012b) Effect of biopriming of radish (Raphanus sativus) seeds with some antagonistic isolates of Trichoderma. J Bot Soc Bengal 66(2):157-160

Neer EJ (1995) Heterotrimeric $G$ proteins: organizers of transmembrane signals. Cell 80:249-257 
Nirmalkar VK, Singh S, Tiwari RS, Said PP, Kaushik DM (2017) Field efficacy of Trichoderma harzianum and Rhizobium against wilt complex of Chickpea. Int J Curr Microbiol App Sci 6:1421-1429

Nogueira KMV, Costa MN, Paula RG, Natividade FCM, Azevedo RR, Silva RN (2015) Evidence of CAMP involvement in cellobiohydrolase expression and secretion by Trichoderma reesei in presence of the inducer sophorose. BMC Microbiol 15. https://doi.org/10.1186/s12866-015-0536-z

Novy V, Schimd M, Eibinger M, Petrasek Z, Nidetzky B (2016) The micromorphology of Trichoderma reesei analyzed in cultivations on lactose and solid lignocellulosic substrate, and its relationship with cellulase production. Biotechnol for Biofuels 9. https://doi.org/10.1186/s13068-0160584-0

Omero C, Inbar J, Rocha-Ramirez V, Herrera-Estrella A, Chet I, Horwitz B (1999) G protein activators and CAMP promote mycoparasitic behaviour in Trichoderma harzianum. Mycol Res 103(12):1637-1642

Parmar HJ, Bodar NP, Lakhani HN, Patel SV, Umrania W, Hassan MM (2015) Production of lytic enzymes by Trichoderma strains during in vitro antagonism with Sclerotium rolfsii, the causal agent of stem rot of groundnut. Afr J Microbiol Res 9:365-372

Ragab MMM, Abada KA, Abd-El-Moneim ML, Abo-Shosha YZ (2015) Effect of different mixtures of some bioagents and Rhizobium phaseoli on bean damping-off under field condition. Inter J of Sci and Eng Res 6(7):1009-1106

Rao SN, Kulkarni S (2003) Effect of Trichoderma spp. on the growth of Sclerotium rolfsii Sacc. J. Biol. Control:17

Reithner B, Brunner K, Schuhmacher R, PeissI I, Seidl V, Krska R, Zeilinger S (2005) The $\mathrm{G}$ protein alpha subunit Tga1 of Trichoderma atroviride is involved in chitinase formation and differential production of antifungal metabolites. Fungal Genet Biol 42(9):749-760

Reithner B, Schuhmacher R, Stoppacher N, Pucher M, Brunner K, Zeilinger S (2007) Signaling via the Trichoderma atroviride mitogen-activated protein kinase Tmk 1 differentially affects mycoparasitism and plant protection. Fungal Genet Biol 44(11):1123-1133

Rifai MA (1969) A revision of the genus Trichoderma. Mycol papers 116:1-56 Rocha-Ramirez V, Omero C, Chet I, Horwitz BA, Herrera-Estrella A (2002) Trichoderma atroviride G-protein alpha-subunit gene tga1 is involved in mycoparasitic coiling and conidiation. Eukaryot Cell 1(4):594-605

Samuels GJ (1996) Trichoderma: a review of biology and systematics of the genus. Mycol Res 100:923-935

Schlick A, Kuhls K, Meyer W, Lieckfeldt E, Boerner T, Messner K (1994) Fingerprinting reveals gamma-ray induced mutation in fungal DNA. Curr Genet 26:74-78

Schuster A, Schmoll M (2010) Biology and biotechnology of Trichoderma. Appl Microbiol Biotechnol 87:787-799

Sengupta J (1995) Physico-chemical response of four different isolates of Trichoderma harzianum, M.Sc. Dissertation, B.C.K.V., Mohanpur 42-98

Shah S, Nasreen S, Sheikh PA (2012) Cultural and morphological characterization of Trichoderma spp. associated with green mold disease of Pleurotus spp. in Kashmir. Res J Microbiol 7:139-144

Spiegel Y, Chet I (1998) Evaluation of Trichoderma spp. as a biocontrol agent against soilborne fungi and plant-parasitic nematodes in Israel. Integrated Pest Manag Rev 3(3):169-175

Srinivasan U, Highley TL, Bruce A (1995) The role of siderophore production in the biological control of wood decay fungi by Trichoderma spp. Biodeterioration-and-Biodegradation-9-Proceedings-of-the-9th-InternationalBiodeterioration-and-Bio-degradation-Symposium,-Leeds,-UK-5-10September-1993 226-231

Suarez B, Rey M, Castillo P, Monte E, Llobell A (2004) Isolation and characterization of PRA1, a trypsin-like protease from the biocontrol agent Trichoderma harzianum CECT 2413 displaying nematicidal activity. Appl Microbiol Biotechnol 65:46-55

Vinale F, D'Ambrosio G, Abadi K, Scala F, Marra R, Turra D, Woo SLM (2004) Application of Trichoderma harzianum (T22) and Trichoderma atroviride (P1) as plant growth promoters, and their compatibility with copper oxychloride. J Zhejiang Univ Sci 30:2-8

Viterbo A, Harel M, Horwitz BA, Chet I, Mukherjee PK (2005) Trichoderma mitogen-activated protein kinase signaling is involved in induction of plant systemic resistance. Appl. Environ. Microbiol 1(10):6241-6246

Weindling R (1934) Studies on lethal principle effective in the parasitic action of Trichoderma lingorum on Rhizoctonia solani and other soil fungi. Phytopathology 24:1153-1179
Weller DM (1988) Biological control of soil borne plant pathogens in the rhizosphere with bacteria. Annual Rev Phytopathol 26:379-407

Xu JR, Hamer JE (1996) MAP kinase and CAMP signalling regulate infection structure formation and pathogenic growth in the rice blast fungus Magnaporthe grisea. Genes Dev 10:2696-2706

Zaher EA, Abada KA, Zyton MA (2013) Effect of combination between bioagents and solarization on management of crown-and stem-rot of Egyptian clover. Amer J of Plant Sci 1(3):43-50

Zamir D, Chet I (1985) Application of enzyme electrophoresis for the identification of the isolates in Trichoderma harzianum. Can J Microbiol 31: 578-580

Zehra A, Dubey MK, Meena M, Upadhyay RS (2017) Effect of different environmental conditions on growth and sporulation of some Trichoderma species. J of Environ Biol 38:197-203

Zeilinger S, Omann M (2007) Trichoderma biocontrol: signal transduction pathways involved in host sensing and mycoparasitism. Gene Regul Syst Bio 1:227-234

Zeilinger S, Reithner B, Scala V, Peissl I, Lorito M, Mach RL (2005) Signal transduction by Tga3, a novel G protein a subunit of Trichoderma atroviride. Appl Environ Microbiol 71(3):1591-1597

\section{Publisher's Note}

Springer Nature remains neutral with regard to jurisdictional claims in published maps and institutional affiliations.

\section{Submit your manuscript to a SpringerOpen ${ }^{\circ}$ journal and benefit from:}

- Convenient online submission

Rigorous peer review

- Open access: articles freely available online

High visibility within the field

- Retaining the copyright to your article

Submit your next manuscript at $>$ springeropen.com 